\title{
Yüksek Güç Faktörlü Şebeke Bağlı Bir PV Sistemin Modellenmesi ve Farklı Işınımlar Altında Kontrolü
}

\author{
Erdem Akboy ${ }^{1 *}$ \\ (İlk Geliş Tarihi 30 Eylül 2019 ve Kabul Tarihi 19 Kasım 2019)
}

(DOI: 10.31590/ejosat.627188)

${ }^{1}$ Yıldız Teknik Üniversitesi, Elektrik-Elektronik Fakültesi, Elektrik Mühendisliği, İstanbul, Türkiye, (ORCID: 0000-0002-1030-9816)

ATIF/REFERENCE: Akboy, E. (2019). Yüksek Güç Faktörlü Şebeke Bağlı Bir PV Sistemin Modellenmesi ve Farklı Işınımlar Altında Kontrolü. Avrupa Bilim ve Teknoloji Dergisi, (17), 794-802.

\section{$\ddot{O} \mathbf{z}$}

Günümüzde gelişen teknolojiye bağlı olarak enerji tüketimi hızla artmakta, buna karşılık enerji kaynakları hızla tükenmektedir. Elektrik enerjisinin üretiminde kullanılan kömür, doğalgaz ve uranyum v.b. yenilenemeyen kaynaklarının kurulumu zordur. Aynı zamanda karbon içeriğine sahip olmaları sebebiyle çevre kirliliğine ve küresel ısınmaya yol açmaktadır. Böylece, güneş ve rüzgar gibi yenilenebilir enerji kaynaklarının kullanımına olan ilgi gün geçtikçe artmaktadır. Özellikle, güneş enerjisinin her daim var olan bir enerji olması sebebiyle daha çok tercih edilmektedir. Güneşten elde edilen enerji ışınıma, panel sıcaklığına ve kirliliğine bağlı olarak değişebilmektedir. Güneş panellerinin çıkışındaki gerilim ve akım arasında nonlineer bir ilişki bulunmakta ve güneşten elde edilen güç sürekli değişmektedir. Bu sebeplerden dolayı, bir güneş panelinden maksimum enerji çekmek üzere Maksimum Güç Noktası Takibi (MGNT) algoritmaları geliştirilmektedir. Bu algoritmalar arasında en yaygın ve uygulaması en kolay olan Sars ve Gözlemle (S\&G) metodudur. Bu çalışmada, yüksek güç faktörlü şebeke bağlı bir PV sistemin modellenmesi ve farklı 1şınımlar altında kontrolü ile şebekeye etkileri incelenmiştir. Sunulan PV sistemi, yükseltici tür dönüştürücü ile tam köprü tür inverterin birleştirilmesi ile oluşturulmuştur. Sistemin girişinde, istenilen güç ve gerilimi sağlamak üzere PV paneller seri olarak bağlanmıştır. Yükseltici tür dönüştürücü, S\&G algoritması ile çalıştırılarak MGNT sağlanmaktadır. Aynı zamanda inverter, Ortalama Akım Mod Kontrol (OAMK) yöntemi ile çalıştırılarak, şebekeye yüksek Güç Faktörü (GF) ile akım verilmesi sağlanmaktadır. Burada her iki devre de analog olarak kontrol edilmektedir. Bu amaçla, $1 \mathrm{~kW}$ gücü ve $100 \mathrm{kHz}$ anahtarlama frekansına sahip şebeke bağlı bir PV sistem kurularak, PSIM programı ile simülasyonu gerçekleştirilmiştir. Geliştirilen sistemde $250 \mathrm{~W}-1000 \mathrm{~W} / \mathrm{m}^{2}$ 1şınım özelliklerine sahip 4 eş panel seri bağlanmıştır. Farklı ışınım ve güç değerleri altında sistem çalıştırlarak, sistemin kontrolü ile şebeke etkileri incelenmiştir. Elde edilen sonuçlarda farklı koşullar altında hedeflenen sistemin, ilgili kontrol algoritmalarına bağlı olarak hızlı dinamik cevap verme süresine sahip olduğu ve şebeke tarafında her daim yüksek GF elde edildiği gözlemlenmiştir.

Anahtar Kelimeler: Sars ve gözlemle metodu, PV sistem, ortalama akım mod kontrol, yüksek güç faktörü

\section{Modelling and Control of A High Power Factor Grid Connected PV Sytem Under Varying Irraditions}

\begin{abstract}
Nowadays, energy consumption is rapidly increasing due to developing technology, whereas energy resources are rapidly exhausting. The use of non-renewable resources such as coil, natural gas and uranium e.t.c. is difficult and cost for the generation of electricity. At the same time, because of their carbon content, it causes environmental pollution and global warming. Thus, interest in the use of renewable energy sources for instance solar and wind is increasing. Solar energy is especially preferred due to endless and free solar energy. The energy obtained from the sun can vary depending on irradiation, panel temperature and pollution. There is nonlinear relationship between the voltage and current at the output of the solar panels and the power obtained from the sun changes. For these reasons Maximum Power Point Tracking (MPPT) algorithms are being developed to draw maximum energy from a solar panel. Among these algorithms, the most common and easiest application is Perturb and Observe (P\&O) method. In this study, modelling and control of a high power factor grid connected solar system under different irraditions and their effects on the grid are investigated. The proposed PV system is constructed by combining a boost converter and a full bridge inverter. At the input of the system, there are many serial solar panes to provide the petitive power and voltage. The boost converter is operated with $\mathrm{P} \& \mathrm{O}$ algorithm to provide
\end{abstract}

\footnotetext{
* Sorumlu Yazar: Yıldız Teknik Üniversitesi, Elektrik-Elektronik Fakültesi, Elektrik Mühendisliği, İstanbul, Türkiye, ORCID: 0000-0002-10309816, erdem.akboy.87@.gmail.com
} 
MPPT. At the same time, the inverter is operated with Average Current Mode Control (ACMC) to supply current to the grid with high Power Factor (PF). Here, both converters are controlled analogously. For this purpose, a grid connected PV system with $1 \mathrm{~kW}$ and $100 \mathrm{kHz}$ switching frequency was established and simulated with PSIM program. In the developed system, 4 panels with $250 \mathrm{~W}-1000$ $\mathrm{W} / \mathrm{m}^{2}$ irradition properties are connected in series. By operating the system under different irradiation and power values, the control of the system and the effects of the line were examined. In the results obtained, it was observed that under different conditions, the proposed system has a fast dynamic response time depending on the relevant control algorithms and always has high $\mathrm{PF}$ on the AC side.

Keywords: Perturb and Observe method, PV system, Average current mode Control, High power factor.

\section{Introduction}

Nowadays, due to technological developments and the welfare level of the societies, energy consumption is increasing and energy resources are rapidly exhausting. Using resources such as coal, diesel, oil, natural gas and nuclear e.t.c. as energy sources is difficult and cost by the producers in electricity generation. In addition, due to the carbon content of the relevant resources, it causes problems such as global warming and environmental pollution. Thus, interest in renewable energy sources as solar and wind is increasing gradually. By the virtue of solar energy is an endless source, which makes it more attractive to be used in energy production. So, the attention on the solar energy systems at academic and industrial areas, has been increasing.

A solar power plant consists of several semiconductor PhotoVoltaic (PV) modules. The operation of PV modules is based on the principle that electrons gain energy when light is applied to them. Thus, basically in a PV system, solar energy is turned into electrical energy in PV modules, directly. This makes PV systems to be considired the most efficient and and well-accepted renewable system. Although a PV system has many advantages, there are many problems. The power which is generated by PV depends upon the solar irradition, panel tempature, panel pollution and load impedance. Also, the output characteristics of the PV module (V-I) is nonlineer, especially under partial shading conditions, which causes only one maximum power point at $\mathrm{P}-\mathrm{V}$ curve. For these reasons, it is necessary to tracking the maximum power point in order to benefit from each PV system at the highest efficiency. For this purpose, several Maximum Power Point Tracking (MPPT) methods are built up. At these methods output can be fed with maximum power from solar input by converters. Thus, Cuk converter (Sahu et al, 2014), buck converter (Gosumbonggota, 2016) and boost (Chowdhury et al, 2017) converters are used to achieve MPPT. In terms of PV, boost converter is more attractive because constant current can be drawn from its input.

P\&O method proposes to track MPP of the PV module by using fixed pertubation value. At this algorithm, the output characterictics $\left(\mathrm{V}_{\mathrm{PV}}-\mathrm{I}_{\mathrm{PV}}\right)$ are measured and the output power $\left(\mathrm{P}_{\mathrm{PV}}\right)$ is calculated of the $\mathrm{PV}$ module. If the variation of the $\mathrm{V}_{\mathrm{PV}}$ and $\mathrm{P}_{\mathrm{PV}}$ at the same direction, the perturbation, or the next value of the $V_{P V}$, is increased. Otherwise next value of $V_{P V}$ is decreased. This operation cycle continues to catch the MPP, periodically. So, it causes to oscillations around the MPP and it leads more losses. Also, response time of the algorithm can change due to the pertubition value. Large step size can yield fast response time but more oscillations. The good solution can be achieved by small step sizes but the tracking speed get slow (Liu and Lopez, 2004). Many new P\&O methods have being developed in order to eliminate these disadvantages and achieve effective solution.

In study of (Liu and Lopez, 2004), it is aimed to accelerate the response time of the P\&O system with smaller perturbation steps by peak current control method. Similarly, in the study (Jung et al, 2005) and (Sharma and Purobit, 2012), it is aimed to reduce oscillations with small perturbation steps against variable weather conditions by hysteresis current control. In (Abdourraziq et al, 2014), a new algorithm is presented with variable perturbation steps to track fast. Similar to (Abdourraziq et al, 2014), in (Jiandong et al, 2018), a new algorithm with variable perturbation steps is presented with grid tie PV inverter system. At this system, the frequency is low and Power Factor (PF) is not referred. Also, the behavior of the system under different power conditions is not studied.

In this study, a high PF grid connected PV system modelling and control under different irradiations and their effects on the grid are presented. The proposed PV system is constructed by combining the DC-DC boost converter and the full bridge inverter. At the entrance of the system, PV panels are connected in series to provide the petitive power and voltage. The boost converter is operated with the P\&O algorithm to provide MPPT. At the same time, the inverter is operated with Average Current Mode (ACM) to supply sinusoidal current to the grid with high PF. Here, both circuits are controlled analogously with fast dynamic response time. For this purpose, a grid connected PV system with a power of $1 \mathrm{~kW}$ and a switching frequency of $100 \mathrm{kHz}$ was installed and simulated with the PSIM program. In the developed system, 4 PV panels with $250 \mathrm{~W}-1000 \mathrm{~W} / \mathrm{m}^{2}$ radiation properties are connected in series. By operating the system under different irradiation and power values, the control of the system and the effects of the line were examined. In the results obtained, it was observed that under different conditions, the proposed system has a fast dynamic response time depending on the relevant control algorithms and always has high PF on the AC side.

\section{Motivation and Background}

\subsection{Basic Principle of PV}

PV generation systems consist of PV cells. Besides, each PV cell consists of large area p-n junctions. When sunlight strikes on this semiconductor, the free electrons in the $\mathrm{n}$ junction gain energy. Through the electrons gaining energy, hole-electron pairs are formed throughout the structure. Thus, the electron-hole redundancy that occurs through the whole structure, allows current to flow through the $\mathrm{p}-\mathrm{n}$ junction and generate electricity. 


\subsection{PV Module Analysis}

An equivalent case of a PV cell is given in Fig.1. At this figure, $\mathrm{I}_{\mathrm{PC}}$ is the cell current, which is generated directly by the sun light, $\mathrm{D}$ is the diode equivalent to $p-n$ junctions, $R_{S}$ is the serial and $R_{S H}$ is the parallel equivalent resistors, $I_{P V}$ and $V_{P V}$ are ouput current and voltage of the PV module, respectively.

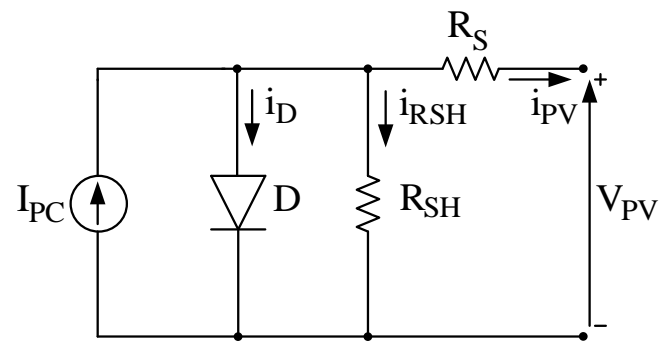

Figure 1. Equivalent PV model

The PV module should be implemented from the mathematical model in equations, which are derived from the equivalent circuit given in Fig. 1.

$$
\begin{gathered}
I_{P V}=I_{P C}-I_{D}-I_{R S H} \\
I_{P C}=I_{S C O} \frac{S}{S_{O}}+C_{t}\left(T-T_{\text {ref }}\right) \\
I_{D}=I_{O}\left(e^{\frac{\mathrm{qV}_{d}}{A K_{s} T}-1}\right) \\
I_{O}=I_{S O}\left(\frac{T}{T_{r e f}}\right)^{3} e^{\frac{q E_{g}}{A}}\left(\frac{1}{T}-\frac{1}{T_{\text {ref }}}\right) \\
T=T_{a}-k_{s} S \\
I_{R S H}=\frac{V_{P V}+I_{P V} R_{S}}{R_{P}}
\end{gathered}
$$

At these equations, $\mathrm{S}$ is the light intensity, $\mathrm{S}_{\mathrm{O}}$ is the light intensity under test conditions, especially under $1000 \mathrm{~W} / \mathrm{m}^{2}$ irradiation, $E_{g}$ is band energy, $T_{a}$ is room temperature, $I_{O}$ is reverse saturation current, $C_{t}$ is temperature coefficient, $T_{\text {ref }}$ is temperature under standart test conditions, $q$ is electron charge $\left(1,610^{-16} \mathrm{C}\right)$, A is ideality factor, $\mathrm{I}_{\mathrm{sco}}$ is short citrcuit current of each solar cell at $\mathrm{T}_{\text {ref }}, \mathrm{K}_{\mathrm{s}}$ describes how the light intensity affects the cell temperature, $\mathrm{k}_{\mathrm{s}}$ is Boltzman constant $\left(1,380650510^{-23} \mathrm{~J} / \mathrm{K}\right)$. So, the ouput characteristics of the PV such as I-V and P-V curves depend on the internal characteristics of the solar module and on outside influences such as the temperature and irradiation level as given in Fig. 2. (Christopher and Ramesh, 2013 )

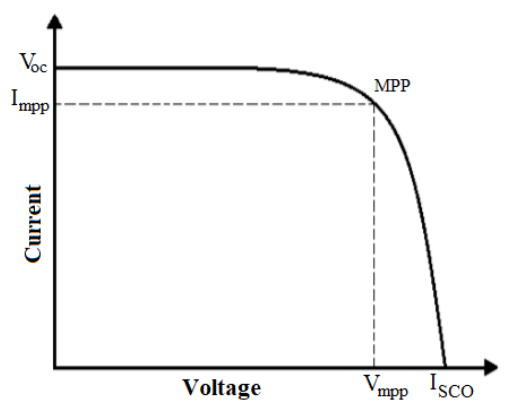

a)

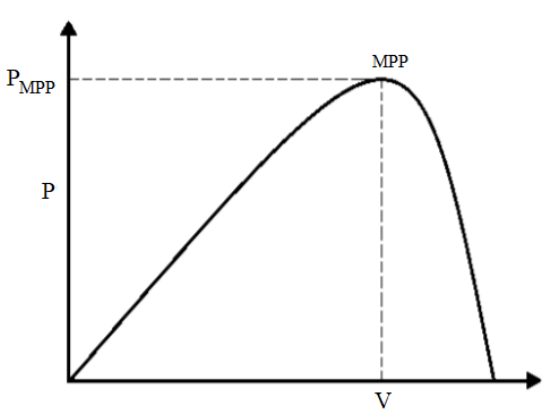

b)

Figure 2. The output characteristics of the PV a) V-I and b) P-V curves

\subsection{Boost Converter}

A boost converter circuit scheme is given in Fig 3.This converter combines of $\mathrm{L}_{b}, \mathrm{~S}_{\mathrm{b}}$ and $\mathrm{D}_{\mathrm{b}}$. At this converter, $\mathrm{V}_{\text {in }}$ and $\mathrm{V}_{\text {out }}$ are input and output voltages, respectively. The relationship between input and output is given as below.

$$
\mathrm{V}_{\text {out }}=\frac{1}{(1-\mathrm{D})} \mathrm{V}_{\text {in }}
$$


In this equation, $\mathrm{D}$ refers the duty cycle of the converter.

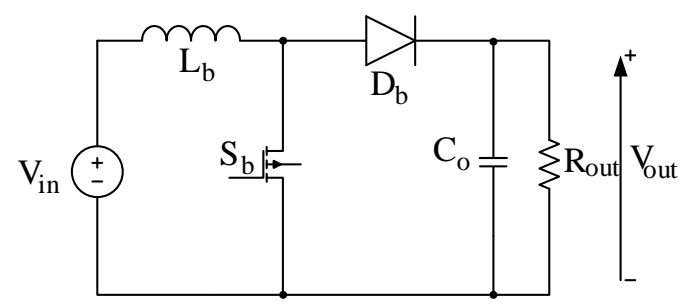

Figure 3. The circuit scheme of conventional boost converter

In this circuit either $\mathrm{S}_{\mathrm{b}}$ or $\mathrm{D}_{\mathrm{b}}$ is on state under ideal conditions. So, there are two operation modes. When the switch is on state, diode is off state and $\mathrm{L}_{b}$ is charged via input, the load is fed by $\mathrm{C}_{\mathrm{o}}$. When the diode is on state, the switch is off state and input and $\mathrm{L}_{b}$ transfer their energies to the output together. At this converter, semiconductors are exposed to output voltage.

Most PV systems require a large capacitor at the output in parallel with panel to achive low voltage ripple. However, the large capacitor reduces the dynamic response of the MPPT systems according to varying athmospheric conditions (Liu and Lopes, 2004). In conventional boost converters inductance is at the input, the input current remains constant and ripples of the input voltage are low. This provides ease of the control, system reliability and minimum size capacitor.

\subsection{Full Bridge Inverter}

Inverters convert DC input to AC output. For this purpose, the DC voltage is applied to the output as positive in the first half and negative in the second half. Sum of the time duration of these periods gives the inverter operation frequency. So, at the grid connected systems, the frequency is equal to the line frequency. A conventional grid tied full bridge inverter scheme is given in Fig 4. In this figure, $V_{d}$ is input voltage, $S_{1}$ and $S_{3}$ are positive and $S_{2}$ and $S_{4}$ are negative switches, $i_{a c}$ and $V_{a c}$ are line current and voltage, respectively. $L_{a c}$ is the filter inductance to smooth line current.

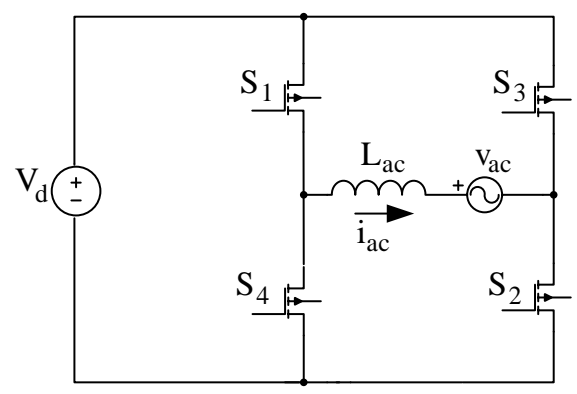

Figure 4. The circuit of the conventional grid tied full bridge inverter

In prinsible, there are two operation modes for this inverter. $S_{1}$ and $S_{2}$ are on state in the first half of $v_{a c}$ and $i_{a c}$ is positive. $S_{3}$ and $\mathrm{S}_{4}$ are on state in the second half of $\mathrm{v}_{\mathrm{ac}}$ and $\mathrm{i}_{\mathrm{ac}}$ is negative. There is dead time between positive and negative term semiconductor control signals to avoid short circuit of DC line. Also, switches are exposed to input voltage at this inverter scheme.

\section{Control Techniques}

\subsection{Perturb and Observe Method (P\&O)}

Perturb and Observe $(\mathrm{P} \& \mathrm{O})$ method is the most known MPPT method. In prinsible, P\&O algorithm takes output voltage and power datas of the PV periodically, and operates by perturbing the panel output voltage according to the variance in these datas. The flowchart and the truth table of implementation of $\mathrm{P} \& \mathrm{O}$ algorithm are given in Fig. 5 and Table 1, respectively. This algorithm increases or decreases the output voltage of PV panel according to previous perturbation cycle.

\section{Table 1. The operation table of $P \& O$ Algorithm}

\begin{tabular}{c|c|c}
\hline Variation of Power & Variation of Voltage & Direction of Next Step \\
\hline+ & + & + \\
\hline+ & - & - \\
\hline- & + & - \\
\hline- & - & + \\
\hline
\end{tabular}




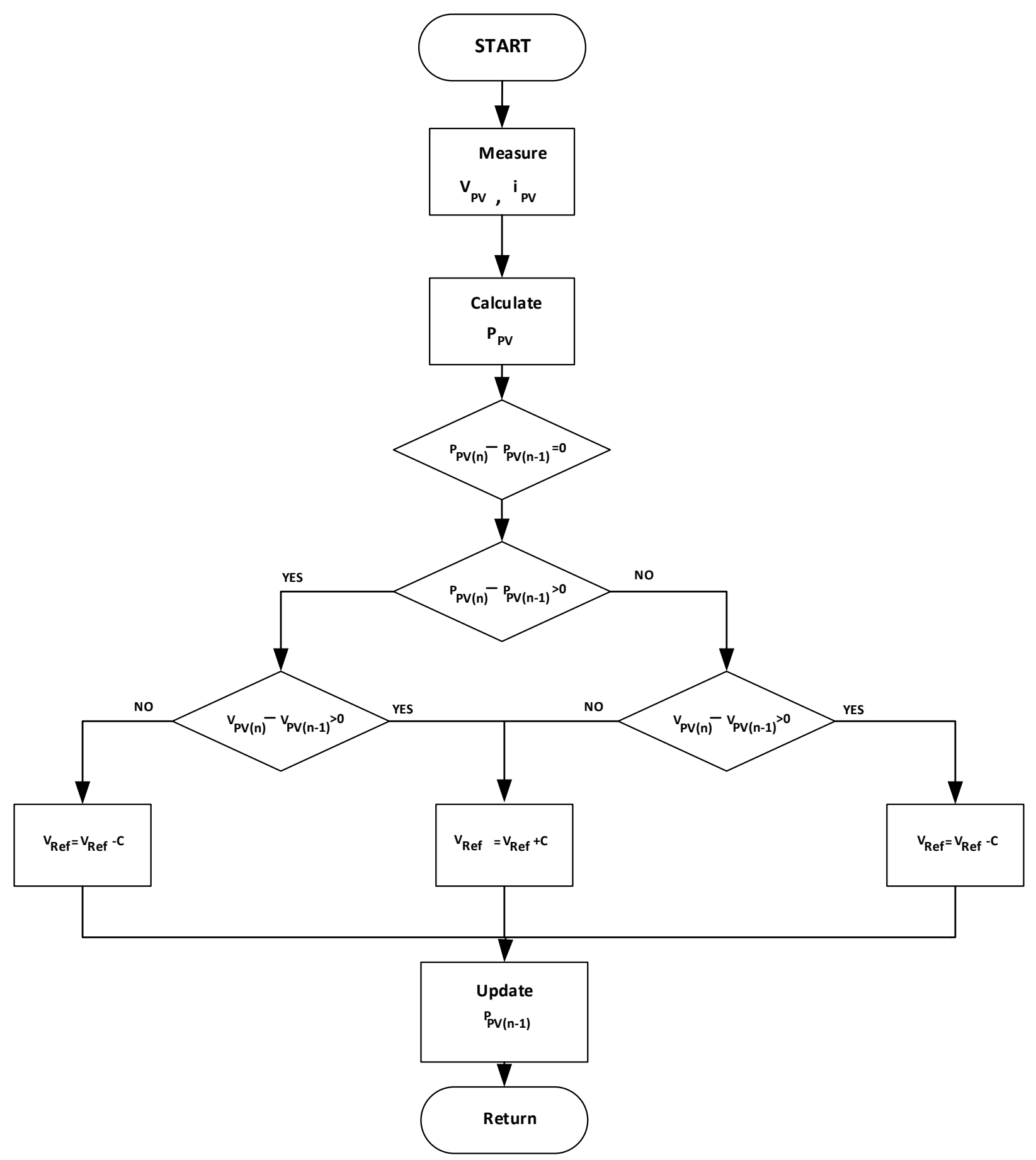

Figure 5. The conventional $P \& O$ algorithm

This algorithm has some drawbacks. After the algorithm reaches the maximum power point, oscillations occurs on the MPP continuously, according to constant or varying atmospheric conditions. These oscillations cause power loss and low efficiency. This problem can be achieved with a sollution by decreasing the perturb rate, but, the tracking response may get slower. So, the optimum solution can be achieved by selecting suitable perturbation step. Thus, at this algorithm, a modulation signal for the PWM with chosing about $\% 10$ of the switching frequency is provided. For this purpose, the error is processed by a PI controller between the ref. and real average amount of the PV output terms (Liu and Lopes, 2004).

\subsection{Average Current Mode Control}

Average Current Mode Control (ACMC) is generally used in Power Factor Correction (PFC) converters. Briefly, this control is intended to settle the actual sensed inductance current at a predetermined current value under constant frequency. So, it requires current amplifier circuit. Also, this control method provides the line current to be in Continuous Current Mode (CCM). The control scheme block diagram is given as follows. 


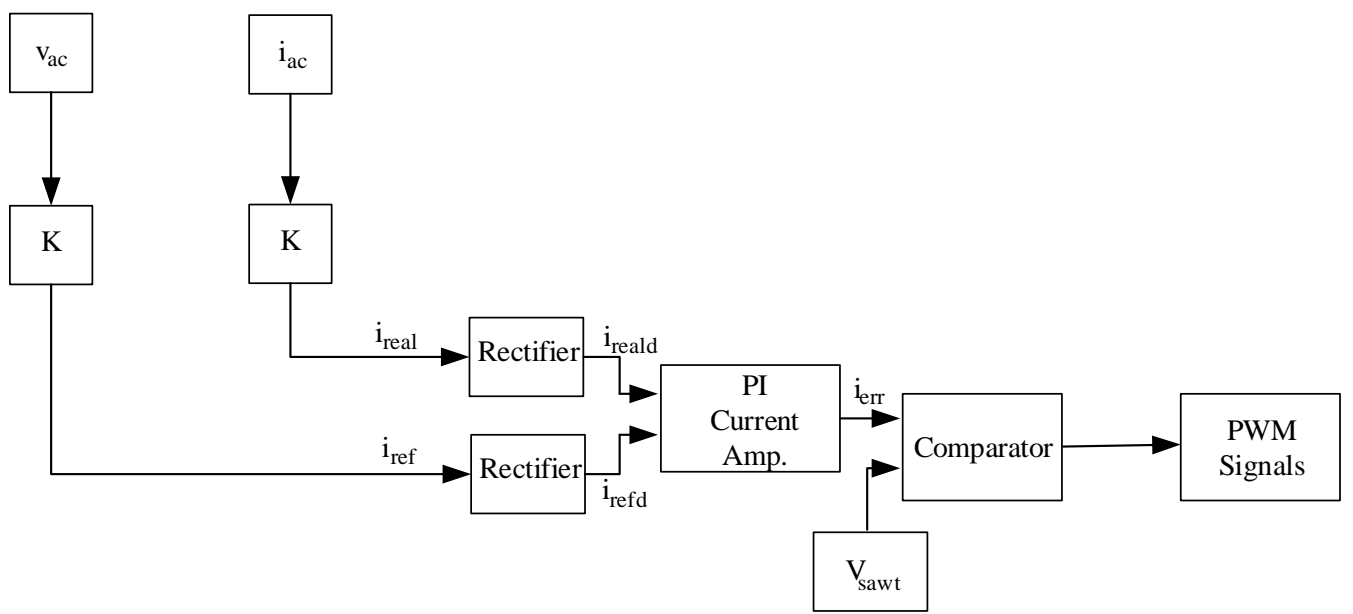

Figure 6. The block diagram of ACMC for grid tied inverters

It can be seen from the figure that it requires two control loops as voltage and current. At grid tied inverter applications, the line voltage $\left(\mathrm{V}_{\mathrm{ac}}\right)$ is sensed firstly to determine reference current value $\left(\mathrm{i}_{\mathrm{ref}}\right)$ of the control. Then, the sensed voltage is rectified via diodes and rectified current reference ( $\left.\mathrm{i}_{\mathrm{refd}}\right)$ is obtained. Besides, the real inductance or line current is sensed with a suitable current sensor $\left(\mathrm{i}_{\text {real }}\right)$ and rectified $\left(\mathrm{i}_{\text {reald }}\right)$. The current error $\left(\mathrm{i}_{\mathrm{err}}\right)$ is obtained by passing the measured and determined current values through the current amplifier circuit. This error is compared with sawtooth or triangular waveform ( $\mathrm{v}_{\text {sawt }}$ ) whose frequency is equal to switching frequency to obtain PWM signals. The current waveform of the line according to this control method is as follows.

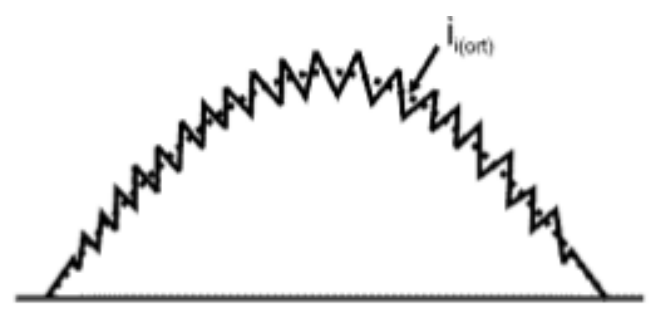

Figure 7. The waveform of the line current with ACMC

\section{Simulation Results}

The block scheme of the proposed grid tied solar system is given in Fig. 8. At this system, MPPT can be provided by P\&O algorithm via boost converter. Besides, high PF can be provided by ACMC via full bridge inverter.

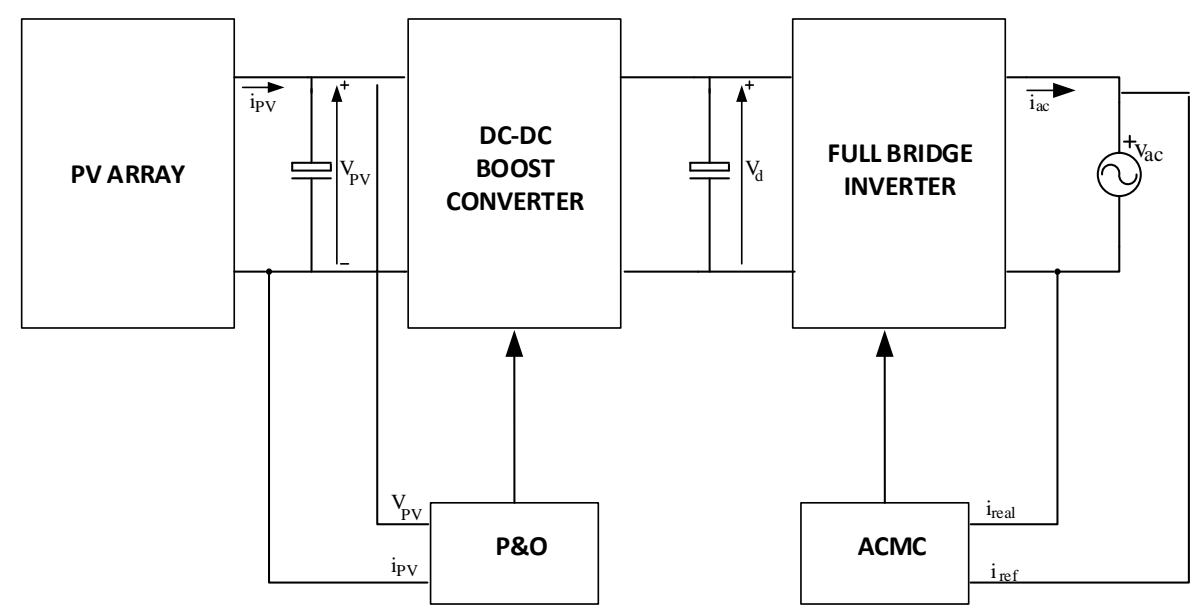

Figure 8. The block scheme of the proposed grid tied PV system

The circuit sheme of the grid tied inverter is given in Fig. 9 with using PSIM simulation programme. The PV module parameters are given in Table 2 under $1000 \mathrm{~W} / \mathrm{m}^{2}$ irradiance and $25^{\circ} \mathrm{C}$ tempature. In this circuit four PV modules are connected serial to obtain 1 $\mathrm{kW}$. 
Avrupa Bilim ve Teknoloji Dergisi

Table 2. The Parameters of PV Module

\begin{tabular}{c|c|c}
\hline Definition & Parameter & Value \\
\hline-- & Number of cells & 72 \\
\hline Nominal power of module & $\mathrm{P}_{\text {nom }}$ & $220 \mathrm{~W}$ \\
\hline $\begin{array}{c}\text { Maximum power of } \\
\text { module }\end{array}$ & $\mathrm{P}_{\max }$ & $236,64 \mathrm{~W}$ \\
\hline Open circuit V. & $\mathrm{V}_{\mathrm{OC}}$ & $52,3 \mathrm{~V}$ \\
\hline Voltage at max. $\mathrm{P}$. & $\mathrm{V}_{\max }$ & $42,7 \mathrm{~V}$ \\
\hline Short circuit current & $\mathrm{I}_{\mathrm{SC}}$ & $5,65 \mathrm{~A}$ \\
\hline Current at max. $\mathrm{P}$ & $\mathrm{I}_{\max }$ & $5,17 \mathrm{~A}$ \\
\hline
\end{tabular}

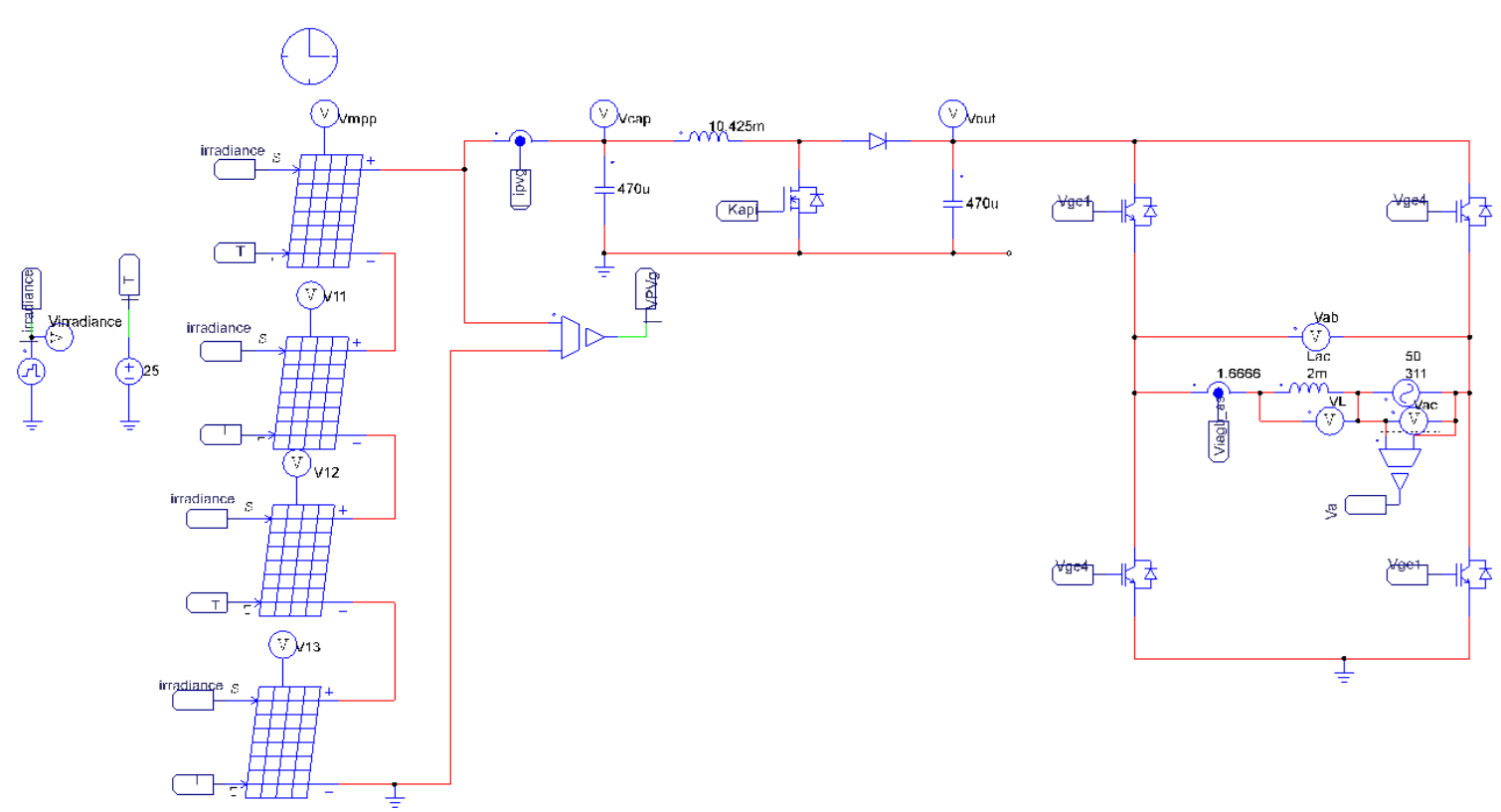

Figure 9. The circuit scheme of the proposed grid tied PV system in PSIM

At this converter, variation in irradiation has been done for specific rate of iteration $(\mathrm{C}=0.3 \mathrm{~V})$ and thus tracking of power is achieved in DC side and high PF is achieved with ACMC in the AC side. For a more detailed analysis, the system has been tested based on varying irradiations at specific time intervals. In the first test, the irradiation values are increased from $200 \mathrm{~W} / \mathrm{m}^{2}$ as follows. AC line current waveform is given in Figure 10. It can be seen from this figure, the system response for varying irraditions is better at higher values. In low irradition values system can not achive high PF, although MPPT can be achieved. PF above $600 \mathrm{~W} / \mathrm{m}^{2}$ is 0,99 and line current THD is \%3.

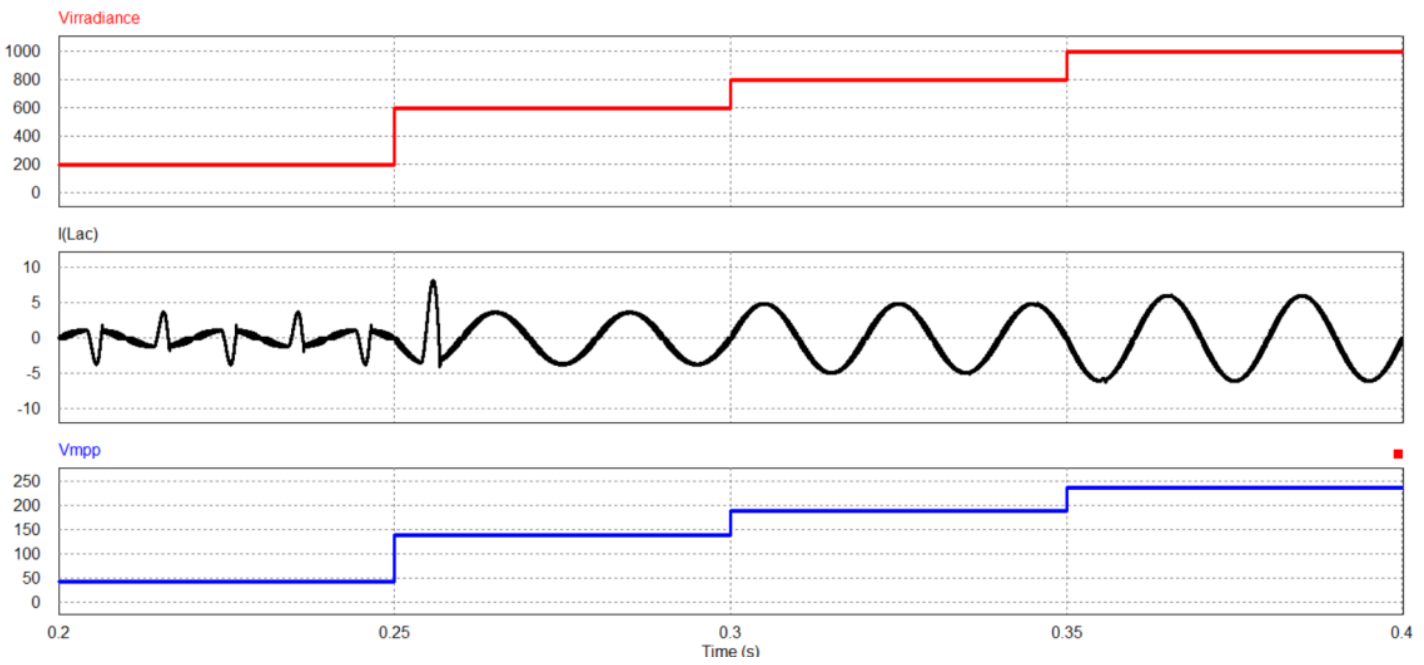

Figure 10. The AC line current under increasing irradition values 
In the second test, the irradiation values are decreased from $1000 \mathrm{~W} / \mathrm{m}^{2}$ as follows and AC line current waveform is given according to varying irradition. It can be seen from this figure, the system response is better than increasing values. PF for all irradiation values is 0,99 and MPPT is achieved perfectly.

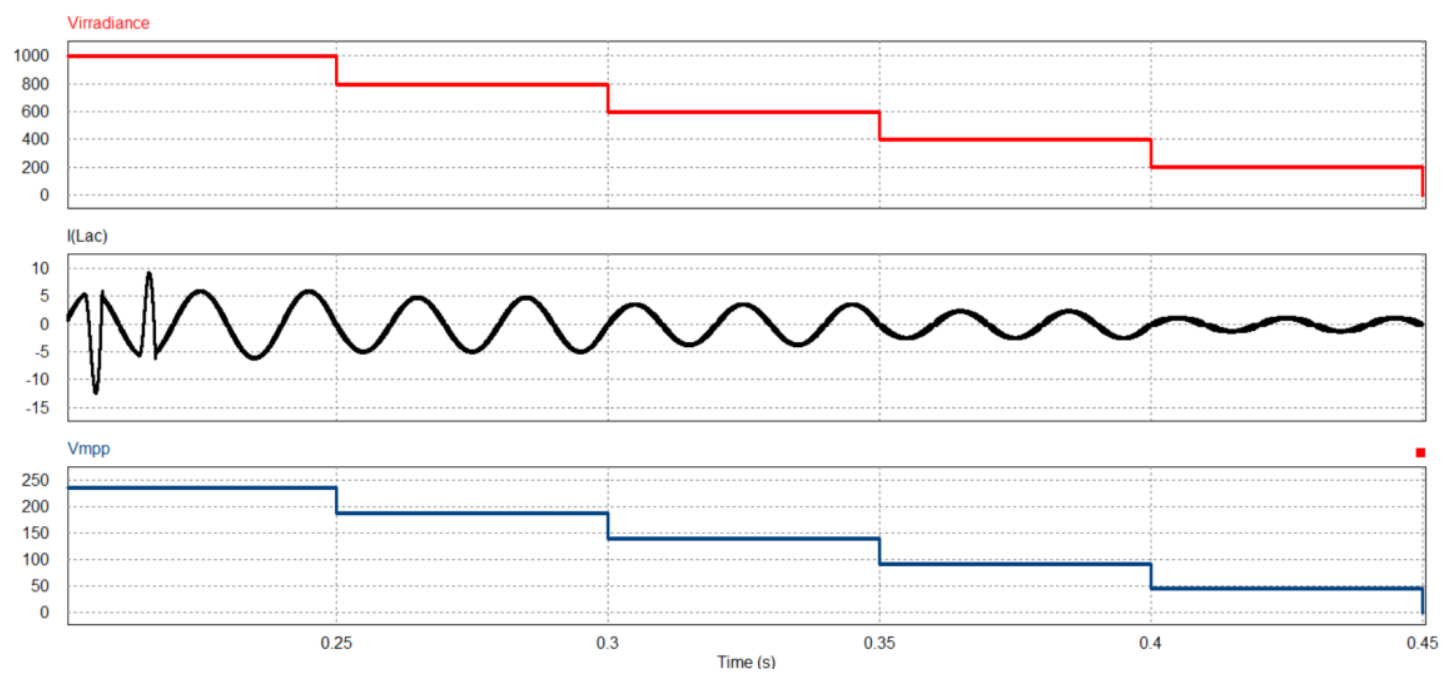

Figure 11. The AC line current under decreasing irradition values

In the third test, the irradiation values are inreased and decreased as follows and AC line current waveform is given according to varying irradition. It can be seen from this figure, the system response is better for both conditions. This is suitable for partial shading conditions. PF for all irradiation values is 0,99 and MPPT is achieved perfectly.

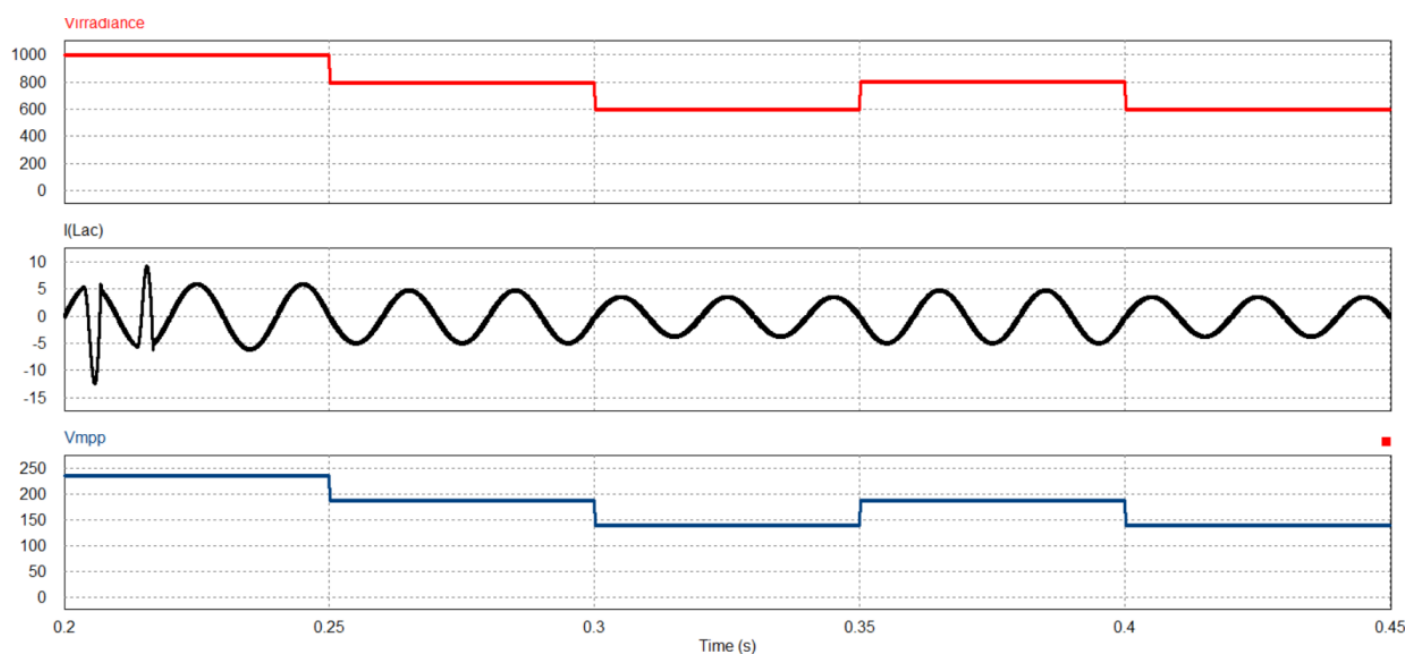

Figure 12. The AC line current under inreasing/decreasing irradition values

\section{Conclusion}

Solar energy is especially preferred due to endless and free solar energy. The energy obtained from the sun can vary depending on irradiation, panel temperature and pollution. In this study, a high PF grid connected PV system model and control of under different irradiations and their effects on the grid are presented. The proposed PV system is constructed by combining a boost converter and a full bridge inverter. The boost converter is controlled by P\&O algortihm to provide MPPT and the inverter is controlled with ACMC to achieve high $\mathrm{PF}$ in the $\mathrm{AC}$ side. Both control algorithms are achieved analoguosly. To definethe performances of the control algortihms, three tests are applied according to varying irraditions. For this purpose, the comparative analysis for a grid connected solar system with $1 \mathrm{~kW}$ power and a switching frequency of $100 \mathrm{kHz}$ was installed and simulated with the PSIM program. Here, fast dynamic response time under varying irraditions are achieved under three test conditions. Also, at this proposed converter, low THD values are obtained for line current. So, both control algorithms can be applied together to achieve MPPT and high PF.

\section{References}

T. P. Sahu, T. V. Dixit and R. Kumar, "Simulation and analysis of perturb and observe MPPT algortihm for PV array CUK converter," Advance in Electronic and Electrical Engineering, vol.4, no. 2, pp. 213-224, 2014 
Z. Erdem, "A review of MPPT algortihms for partial shading conditions", in Special Issue of the 3rd International Conference on Computational and Experimental Science and Engineering, 2016, Turkey, pp.1128-1133, doi:10.12693/APhysPolA.132.1128

A. Chowdhury, T. Rout and Prof. S.Samal," Analysis of perturbation and observation technique used in maximum power point tracking for photovoltaic systems", International Journal of Engineering Technology Science and Research, vol.4, no. 11, pp. 99$105,2017$.

M. Engin and T. Gülersoy," Hibrid güç sistemleri için evirici tasarımı," European Journal of Science and Technology, no. 14, pp. 228234, 2018. doi: 10.31590/ejosat.429365.

B. N. Alajmi and F. A. Alkandari, "Modified perturbation and observation technique for partially shaded photovoltaic systems in microgrids", Journal of Clean Energy Technologies, vol.4, no.1, pp. 32-35. doi: 10.7763/JOCET.2016.V4.249.

K. Kobayashi, I. Takano and Y. Sawada, "A study on a two Stage maximum power point tracking control of a photovoltaic system under partially shaded insolation conditions," in IEEE Power Engineering Society General Meeting, vol. 4, 2003, Canada, pp. 2612-2167, doi: $10.1109 /$ PES.2003.1271058

X. Liu and L. A. C. Lopes," An improved perturbation and observation maximum power point tracking algorithm for PV arrays" in IEEE 35th Annual Power Electronics Specialists Conference, 2004, Germany, pp.2005-2010. doi: 10.1109/PESC.2004.1355425.

L. Ch.-xia and L. Li-qun, "An Improved Perturbation and Observation MPPT Method of Photovoltaic Generate System," in 4 th IEEE Conference on Industrial Electronics and Applications, 2009, China, pp. 2966-2970, doi: 10.1109/ICIEA.2009.5138752.

A. Ajder, A. Durusu and İ. Nakir, "Impact of Climatic Conditions on PV Array's Optimum Tilt Angle," European Journal of Science and Technology, No. 13, pp. 84-90, 2018. Doi: 10.31590/ ejosat.418559.

P. Sivachandran, D. Lakshmi and R. Janani, "Survey of maximum power point tracking techniques in solar PV system under partial shading conditions," ARPN Journal of Engineering and Applied Sciences, vol.10, no.1, 2015, pp. 256-264.

Y. Jung,. J. So, G. Yu, J. Choi," Improved perturbation and observation method (IP80) of MPTT control for photovoltaic power systems," in Conference Record of the Thirty-first IEEE Photovoltaic Specialists Conference, 2005, USA, pp. 1788- 1791 Doi: 10.1109/PVSC.2005.1488498.

D. K. Sharma and G. Purohit, "Advanced Perturbation and Observation (P\&O) based Maximum Power Point Tracking (MPPT) of a Solar Photo-Voltaic System," in IEEE 5th India International Conference on Power Electronics (IICPE), 2012, India, doi: 10.1109/IICPE.2012.6450411.

M. A. Abdourraziq, M. Ouassaid, M. Maaroufi, S. Abdourraziq," Modified P\&O MPPT technique for photovoltaic systems," in International Conference on Renewable Energy Research and Applications, 2014, Spain, pp. 728-733, doi: 10.1109/ICRERA.2013.6749849.

P. U. Mankar and R.M. Moharil, "Comparative analysis of the perturb and observe and incremental conductance MPPT methods," International Journal of Research in Engineering and Applied Sciences, vol.2, no.2, pp. 60-66, 2014.

M. A. Elgendy, B. Zahawi and D. J. Atkinson," Evaluation Of Perturb And Observe Mppt Algorithm Implementation Techniques", in IEEE conf. on Renewable energy conversion, 2009, Bristol, pp. 1-6. doi: 10.1049/cp.2012.0156.

D.Jiandong, X. Ma and S.Tuo, "A variable step size P\&O MPPT algorithm for three-phase grid-connected PV systems," in China International Conference on Electricity Distribution, 2018, China, pp. 1997-2001, doi: 10.1109/CICED.2018.8592040.

M. L. Azad, S. Dasb, P. K. Sadhu, B. Satpati , A. Guptab, P. Arvindb, "P\&O algorithm based MPPT technique for solar PV System under different weather conditions," in International Conference on circuits Power and Computing Technologies, 2017, India, Doi: $10.1109 /$ ICCPCT.2017.8074225.

I. W.Christopher and Dr. R. Ramesh, "Comparative study of P\&O and InC MPPT algorithms," American Journal of Engineering Research (AJER), vol.2, no.12, pp.402-408, 2013.

T. Esram, and P. L. Chapman, "Comparison of photovoltaic array maximum power point tracking techniques, "IEEE Transactions on Energy Conversion, vol. 22, no.2, pp. 439 - 449, 2007.doi: 10.1109/TEC.2006.874230.

J. Gosumbonggota," Maximum power point tracking method using perturb and observe algorithm for small scale DC voltage converter," in International Electrical Engineering Congress, Karachi, 2016, doi: 10.1016/j.procs.2016.05.065 